\title{
Ocular surface squamous neoplasia: Population demographics, pathogenesis and risk factors
}

\begin{tabular}{|c|c|}
\hline $\begin{array}{l}\text { Authors: } \\
\text { Roland Hollhy } \\
\text { Susan William } \\
\text { Pamela Miche }\end{array}$ & $\begin{array}{l}\operatorname{mer}^{1,2} \\
s^{1} \text { (1) } \\
\operatorname{low}^{3} \text { (1) }\end{array}$ \\
\hline $\begin{array}{l}\text { Affiliations: } \\
{ }^{1} \text { Department } \\
\text { Neuroscience } \\
\text { Ophthalmolo } \\
\text { the Witwater } \\
\text { Johannesburg }\end{array}$ & $\begin{array}{l}\text { s, Division of } \\
\text { sy, University of } \\
\text { rand, } \\
\text { South Africa }\end{array}$ \\
\hline $\begin{array}{l}{ }^{2} \text { The Cornea } \\
\text { Johannesburg }\end{array}$ & $\begin{array}{l}\text { oundation, } \\
\text {, South Africa }\end{array}$ \\
\hline $\begin{array}{l}{ }^{3} \text { Cytology Uni } \\
\text { Health Labora } \\
\text { and Departm } \\
\text { Anatomical P } \\
\text { Faculty of Hea } \\
\text { University of } \\
\text { Witwatersran } \\
\text { Johannesburg }\end{array}$ & $\begin{array}{l}\text {, National } \\
\text { tory Service } \\
\text { ent of } \\
\text { thology, } \\
\text { Ith Sciences, } \\
\text { he } \\
\text { d, } \\
\text {, South Africa }\end{array}$ \\
\hline $\begin{array}{l}\text { Correspondin } \\
\text { Roland Hollhu } \\
\text { hollhumer@g }\end{array}$ & $\begin{array}{l}\text { g author: } \\
\text { mer, } \\
\text { mail.com }\end{array}$ \\
\hline $\begin{array}{l}\text { Dates: } \\
\text { Received: } 17 \text { J } \\
\text { Accepted: } 04 \\
\text { Published: } 23\end{array}$ & $\begin{array}{l}\text { an. } 2020 \\
\text { Mar. } 2020 \\
\text { June } 2020\end{array}$ \\
\hline $\begin{array}{l}\text { How to cite th } \\
\text { Hollhumer R, } \\
\text { Michelow P. O } \\
\text { squamous nec } \\
\text { Population de } \\
\text { pathogenesis } \\
\text { Afr Vision Eye } \\
2020 ; 79(1) \text {, a } \\
\text { org/10.4102/a }\end{array}$ & $\begin{array}{l}\text { is article: } \\
\text { Williams S, } \\
\text { cular surface } \\
\text { plasia: } \\
\text { mographics, } \\
\text { and risk factors. } \\
\text { Health. } \\
\text { 53. https://doi. } \\
\text { veh.v79i1.553 }\end{array}$ \\
\hline $\begin{array}{l}\text { Copyright: } \\
\text { (c) 2020. The } A \\
\text { Licensee: AOS } \\
\text { is licensed un } \\
\text { Creative Comr } \\
\text { Attribution Lic }\end{array}$ & $\begin{array}{l}\text { IS. This work } \\
\text { IS. } \\
\text { der the } \\
\text { nons } \\
\text { ense. }\end{array}$ \\
\hline Read online: & \\
\hline 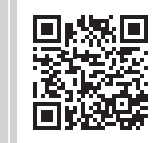 & $\begin{array}{l}\text { Scan this QR } \\
\text { code with your } \\
\text { smart phone or } \\
\text { mobile device } \\
\text { to read online. }\end{array}$ \\
\hline
\end{tabular}

Authors:

\section{Affiliations:}

Department of

the Witwatersrand,

Johannesburg, South Africa

${ }^{2}$ The Cornea Foundation,

${ }^{3}$ Cytology Unit, National

Health Laboratory Service

and Department of

Anatomical Pathology,

University of the

Witwatersrand,

ponding author:

Roland Hollhume

Dates:

Received: 17 Jan 2020

Accepted: 04 Mar. 2020

How to cite this article:

Hollhumer R, Williams $S$

squamous neoplasia:

Population demographics,

pathogenesis and risk factors.

Copyright:

C) 2020. The Author(s).

Licensee: AOSIS. This work

licensed under the

ution License.
Background: Ocular surface squamous neoplasia (OSSN) is a unifying term used to describe conjunctival intra-epithelial neoplasia, squamous cell carcinoma in situ and invasive squamous cell carcinoma.

Aim: The aim of this article was to describe the demographics, clinical features, pathogenesis and risk factors of OSSN.

Method: A literature search was conducted using the search criteria 'ocular surface squamous neoplasia', 'diagnosis', 'epidemiology', 'pathogenesis' and 'risk factors'.

Results: Ocular surface squamous neoplasia is the most common ocular tumour, with incidence rates ranging from 0.01 to 3.4 per 100000 persons/year. There are two main patterns of disease presentation: older white males in temperate climates where human immunodeficiency virus (HIV) and human papilloma virus (HPV) are not associated; and a younger patient population in tropical climates where HIV and HPV are more prevalent. The pathogenesis primarily revolves around ultraviolet B exposure and HPV infection that cause genetic mutations and uncontrolled cellular proliferation, whilst HIV infection and vitamin A impair tumour surveillance mechanisms. Ocular surface squamous neoplasia is first suspected clinically before formal confirmation of the diagnosis. Morphologically, it can be divided into three groups: placoid, nodular and diffuse. Placoid lesions can further be sub-divided into gelatinous, leukoplakic and papilliform lesions. Nodular lesions have the poorest prognosis, with the highest risk of metastasis and recurrence.

Conclusion: Ocular surface squamous neoplasia is a common ocular tumour associated with ultraviolet radiation, HPV and HIV infection. The pathogenesis revolves around acquired genetic mutations, unregulated cellular proliferation and impaired tumour surveillance mechanisms.

Keywords: conjunctival neoplasm; squamous cell cancer; human immunodeficiency virus; human papillomavirus; ultraviolet radiation.

\section{Introduction}

Squamous cell carcinoma of conjunctiva was first described by Von Graefe in 1860. Owing to inconsistency in terminology used in the literature, Lee and Hirst coined the term 'ocular surface squamous neoplasia' (OSSN) in 1995 to describe all conjunctival squamous tumours. ${ }^{1}$ These include conjunctival intra-epithelial neoplasia (CIN), squamous cell carcinoma in situ and invasive squamous cell carcinoma. Conjunctival intra-epithelial neoplasia lesions are characterised by dysplastic cells that progressively occupy the conjunctival epithelium from the basal layer. When the entire epithelium consists of dysplastic cells with an intact basement membrane, the lesion is called squamous cell carcinoma in situ. Once the basement membrane is breached and the substantia propria of the conjunctiva is involved, a diagnosis is made of invasive squamous cell carcinoma. ${ }^{1}$

Ocular surface squamous neoplasia is the most common ocular tumour with an incidence of 0.031.9 per 100000 persons / year in the United States and Australia. In sub-Saharan Africa (SSA), the incidence is 1.6-3.4 per 100000 persons/year. ${ }^{1,2,3}$ The large difference between these two population groups is largely attributed to the human immunodeficiency virus (HIV) pandemic in SSA. The prevalence of disease in Africa is higher in females, which is likely associated with the higher prevalence of human papilloma virus (HPV) and HIV in this cohort. Two main patterns of disease presentation have been identified: older white males in temperate climates, where HIV and HPV are not associated; and a younger patient population in tropical climates, where HIV and HPV are more prevalent. ${ }^{3}$ Sub-Saharan Africa falls into the latter category with an estimated HIV infection rate of $13 \%$ in South Africa in $2018 .^{4}$ 


\section{Pathogenesis}

The corneal limbus is a transition zone between the conjunctiva and cornea. Stem cells reside in niches in the limbus that are responsible for continuous regeneration of the corneal epithelium and act as a barrier to prevent conjunctivalisation of the cornea. These niches are maximal in the nasal limbus, corresponding to the most common location for the development of OSSN. Ocular surface squamous neoplasia develops from the basal layer of the epithelium to involve full thickness before breaking through the basement membrane to become invasive squamous cell carcinoma. The following three main events characterise the development of OSSN: DNA damage, failed DNA repair and decreased immunity. ${ }^{5}$

DNA damage is the central factor responsible for OSSN and could be divided into genetic and epigenetic damage. Genetic damage primarily involves oncogenes and tumour suppressor genes, whereas epigenetic factors affect cell function and may cause DNA mutations. The two main factors responsible for DNA damage are ultraviolet (UV) radiation and HPV infection. In the UV spectrum, ultraviolet-A (UVA) and ultraviolet-B (UVB) can cause damage. Ultraviolet-A causes damage by inducing production of reactive oxygen species that cause DNA strand breaks. These can be repaired, and no study has found evidence of UVA-induced damage in OSSN. Ultraviolet-B causes damage by cross-linking adjacent bases which results in the formation of cyclobutene pyrimidine dimers (CPD). The most common dimer transition is the $\mathrm{CC} \rightarrow \mathrm{TT}$ transition in the p53 tumour suppressor gene, which results in the loss of its cellular repair mechanism. ${ }^{5}$

Human papilloma virus is a double stranded DNA virus with its global prevalence ranging from $1 \%$ to $26 \%{ }^{6}$ It is predominantly classified as mucosal and cutaneous types, with the mucosal type further classified into high- and lowrisk types according to their association with cervical cancer. It is an epitheliotropic virus with an affinity for transitional mucosal surfaces such as the corneal limbus. To cause infection, the virus requires a break in the epithelial surface, after which it invades the basement membrane, infects the epithelial cells and internalises itself in the cell nucleus. Ultraviolet-B exposure is known to cause reactivation of the virus. Human papilloma virus infection has its primary oncogenic effect by blocking the retinoblastoma and p53 gene. Functionally, it is divided into the following three regions: the early, late and long-control regions. The early region codes for proteins E1-E7, with E6 and E7 playing an important role in the pathogenesis of OSSN. ${ }^{7}$ Under normal conditions, basal epithelial cells leave the cell cycle to migrate across the cornea, E7 causes the cells to remain active in the cell cycle by inactivating the retinoblastoma gene $(p R B)$, keeping the cells in a proliferative state. E6 binds to the $p 53$ gene, suppressing its cellular repair function. Lastly, in high risk HPV types, E6 and E7 cause DNA instability. ${ }^{5}$

DNA repair is maintained by cell cycle checkpoints and the p53 tumour suppressor gene. The $p 53$ gene is responsible for arresting cells with DNA damage in the cell cycle. The DNA is then repaired before re-entering the cell cycle, failure to repair damage results in apoptosis. Mutations of the $p 53$ gene therefore results in DNA instability and failure of the cellular repair mechanism. ${ }^{5}$

Lastly, the immune system is responsible for identifying tumour cells and destroying them. Ultraviolet radiation suppresses cellular immunity and HIV infection reduces immunosurveillance. Human immunodeficiency virus infection also has been associated with increased infection with oncogenic viruses such as HPV and causes a chronic state of inflammation, both of which have oncogenic effects. Vitamin A plays an important role in maintaining the integrity of ocular surface, immune-homeostasis and maintaining normal stem cell differentiation. It is therefore hypothesised that vitamin A deficiency compromises epithelial integrity which allows for HPV invasion and the associated sequelae, impairs cellmediated immunity and stem cell differentiation. ${ }^{5}$ Human immunodeficiency virus infection has been associated with both vitamin A deficiency and HPV infection. ${ }^{8}$

Altogether, the oncogenic process is initiated by UVB radiation that induces genetic and epigenetic damage and activates latent HPV. The oncoproteins from HPV infection prevent the arrest of mutated cells and result in uncontrolled proliferation, whilst HIV infection, UVB and vitamin A deficiency weaken the tumour surveillance mechanism.

\section{Clinical presentation}

Ocular surface squamous neoplasia may present with nonspecific symptoms such as foreign body sensation, redness, irritation and a variable degree of visual impairment. ${ }^{1,9}$ The average duration of symptoms is 3 months and most patients present within 6 months. ${ }^{1} \mathrm{~A}$ growth is noticed by the patient on the eye surface, or only identified on clinical examination. The macroscopic appearance of the lesion is typically raised, well demarcated from the surrounding conjunctiva, and has a variable degree of pigmentation and feeder vessels. ${ }^{1}$ In African patients, the lesions can have a greater degree of pigmentation. ${ }^{3}$ They are most commonly located at the nasal limbus of the eye, extending onto the adjacent cornea and conjunctiva. ${ }^{1}$ Morphologically, OSSN is divided into the following three groups: placoid, nodular and diffused., ${ }^{2,10}$ Placoid lesions are further sub-divided into gelatinous, leukoplakic and papilliform lesions. Gelatinous lesions (Figures 1a and $1 b$ ) are the most common type with a velvety, tufted vascular appearance. Leukoplakic lesions (Figures 1b, 1c and 1f) have a characteristic white appearance because of large amounts of keratin on the surface. Papilliform lesions (Figure 1d) resemble benign papillomas with a typical frond like appearance. Nodular lesions (Figure 1e) are circumscribed rapidly by growing nodules that invade the adjacent conjunctiva. They are less common, with a higher risk of metastasis and recurrence. Diffused lesions (Figure 1f) are the rarest form of OSSN; they are flatter and fimbricated, covering a larger surface area of the cornea and conjunctiva. These may initially be misdiagnosed as chronic conjunctivitis, 
pannus or limbal stem cell failure. ${ }^{1,11}$ Corneal extension of OSSN is seen clinically as a progressive superficial grey epithelial opacity. ${ }^{10,12}$ The masses are usually mobile, with a fixed lesion suspicious of invasive squamous cell carcinoma where direct invasion is the primary form of spread. ${ }^{9}$ At presentation, scleral invasion has been found in
$30 \%-37 \%$, intra-ocular invasion in $11 \%$ and orbital extension $11 \%-15 \% \cdot{ }^{13,14}$ Ocular surface squamous neoplasia is staged by the American Joint Committee on Cancer according to the tumour, node, metastasis (TNM) classification (Table 1$) \cdot{ }^{15}$ Important nuances of this classification include: all CIN lesions fall into the tumour in situ (Tis) stage; only
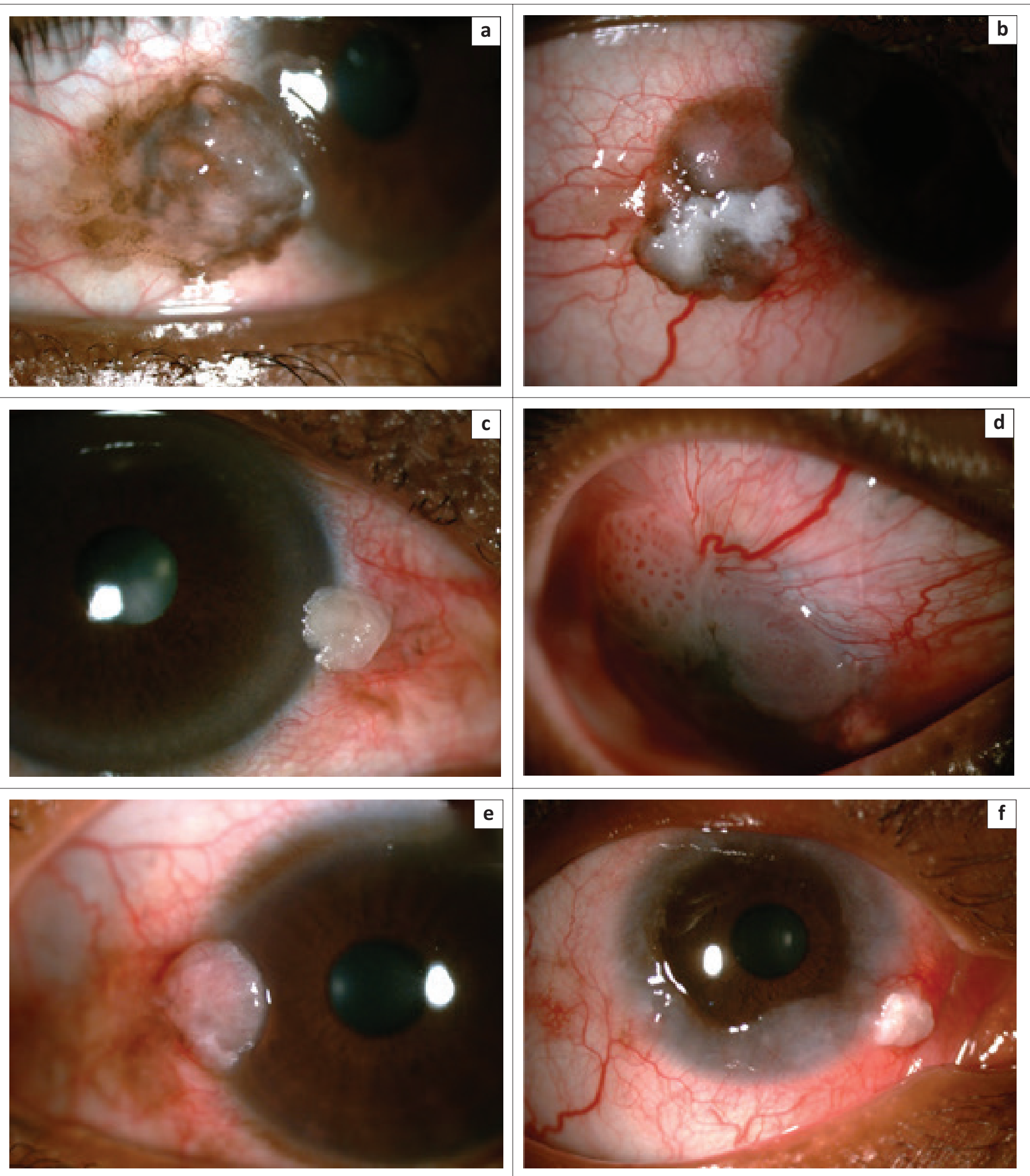

Source: Photos courtesy of Dr Roland Höllhumer

FIGURE 1: Anterior segment images of ocular surface squamous neoplasia morphology. (a) Gelatinous, (b) gelatinous with an area of leukoplakia, (c) leukoplakic, (d) papilliform, (e) nodular, (f) diffused with an area of leukoplakia. 
invasive squamous cell carcinoma is staged from T1-T4; corneal extension of a lesion does not imply invasion; invasion of the cornea only occurs if there is a breach in Bowman's membrane (seen on ultra-sound biomicroscopy or at surgery). ${ }^{16}$ The differential diagnosis for OSSN and their differentiating features are highlighted in Table 2.

\section{Risk factors}

The leading risk factors for the development of OSSN are UVB radiation exposure and infection with HPV. ${ }^{2}$ Other predisposing factors include cigarette smoke exposure, vitamin A deficiency, ocular surface injury, chronic ocular inflammation (e.g. allergic conjunctivitis), exposure to petroleum chemicals, chronic viral infections (hepatitis B and C, HIV) and immunodeficiency. ${ }^{2,20,21}$ With a poorly understood pathophysiology, the aetiology is most likely multifactorial.

\section{Ultraviolet-B}

Ultraviolet-B is the main risk factor for OSSN by causing DNA mutations, activating latent HPV and impairing cancer immunosurveillance. ${ }^{5}$ It has been found that spending more than $50 \%$ of time outdoors in the first 6 years of life, living

TABLE 1: American Joint Committee on Cancer staging for ocular surface squamous neoplasia.

\begin{tabular}{ll}
\hline T category & T criteria \\
\hline TX & Primary tumour cannot be assessed. \\
T0 & No evidence of primary tumour. \\
Tis & Carcinoma in situ. \\
T1 & $\begin{array}{l}\text { Tumour ( } \leq 5 \mathrm{~mm} \text { in greatest dimension) invades through the conjunctival } \\
\text { basement membrane without invasion of adjacent structures. }\end{array}$ \\
T2 & $\begin{array}{l}\text { Tumour ( }>5 \mathrm{~mm} \text { in greatest dimension) invades through the conjunctival } \\
\text { basement membrane without invasion of adjacent structures. }\end{array}$ \\
T3 & Tumour invades adjacent structures (excluding the orbit). \\
T4 & Tumour invades the orbit with or without further extension. \\
T4a & Tumour invades orbital soft tissues without bone invasion. \\
T4b & Tumour invades bone. \\
T4c & Tumour invades adjacent paranasal sinuses. \\
T4d & Tumour invades brain. \\
\hline
\end{tabular}

Source: Amin MB, Edge SB, Greene FL, et al., editors. AJCC cancer staging manual. Cham Springer; 2017. https://doi.org/10.1007/978-3-319-40618-3 within $30^{\circ}$ of the equator, having fair skin and pale irides are risk factors for UVB-induced OSSN. ${ }^{1}$ Newton et al. found a clear association between UVB exposure and OSSN, with $49 \%$ decrease in the incidence of disease for every $10^{\circ}$ increase in latitude. ${ }^{22}$ These lesions occur most commonly at the nasal limbus because of the focussing effect of the cornea on temporal incident light, which increases light intensity by a factor of $20 .{ }^{23} \mathrm{~A}$ Kenyan cohort of predominantly HIV positive participants showed that greater time spent in the sun $(6.9 \mathrm{~h} /$ day vs. $4.6 \mathrm{~h} /$ day, $p<0.001$ ) was found to be associated with OSSN, and the use of hats or caps had a protective effect (odds ratio (OR): 0.22 , 95\% confidence interval (CI): $0.07-$ 0.67). Sunglasses were not shown to offer any protection, which is most likely attributed to the lack of protection from temporal incident light. ${ }^{20} \mathrm{~A}$ United States study of predominantly immune competent adults similarly found an association with patients in latitudes of less than $35^{\circ}$ and a higher erythemal exposure rate of $>170$, indicating an association between OSSN and UV exposure. ${ }^{24}$ Clear et al. ${ }^{25}$ found an increased incidence of OSSN in patients within $30^{\circ}$ of the equator in Malawi. This association was made in African patients before the onset of HIV pandemic, highlighting the importance of UVB and the compounded effect of the two associated factors. ${ }^{25,26}$

\section{Human papilloma virus}

Human papilloma virus has been described as a risk factor for the development of OSSN and can be detected with immunohistochemistry, in situ hybridisation and polymerised chain reaction (PCR) (in order of increasing sensitivity). ${ }^{27}$ This association was first made by McDonnel et al. ${ }^{28}$ in 1989, when HPV16 was found in $100 \%(n=6)$ of OSSN lesions. This was followed by numerous studies that investigated association between mucosal HPV and OSSN. The results of these studies were inconsistent, with an association found in 0 to $100 \%$ of cases with an average prevalence of $34 \%{ }^{7,28,29,30,31,32,33,34}$ Most studies have found an association with HPV 16 and HPV 18, although most studies only looked for the mucosal types based on the association between cervical cancer and HPV. Ateenyi-

TABLE 2: Differential diagnosis of ocular surface squamous neoplasia and its distinguishing features.

\begin{tabular}{|c|c|}
\hline Condition & Distinguishing features \\
\hline Pterygium & $\begin{array}{l}\text { A benign fibrovascular wing-like growth of the conjunctiva that develops at the limbus in the palpebral fissure and extends onto } \\
\text { the cornea. }{ }^{17}\end{array}$ \\
\hline Pingueculum & A benign fibrovascular growth of the conjunctiva that develops at the limbus in the palpebral fissure without corneal extension..$^{17}$ \\
\hline Papilloma & $\begin{array}{l}\text { Occurs in younger patients as a fleshy pink mass with frond-like projections. May be present anywhere on the ocular surface, not } \\
\text { only at the limbus. May need histology to distinguish from OSSN. } \text {. }^{1,12}\end{array}$ \\
\hline Hereditary benign intraepithelial dyskeratosis & A heritable condition characterised by fleshy perilimbal plaques that can also be found in the buccal mucosa. ${ }^{18}$ \\
\hline Nevus & $\begin{array}{l}\text { Mostly a pigmented lesion that occurs in younger patients. Located in the interpalpebral zone from the limbus to the caruncle. } \\
\text { May have cysts and become inflamed or increase in size during puberty. } \text {. }^{1,12}\end{array}$ \\
\hline Malignant melanoma & $\begin{array}{l}\text { Mostly arises from pre-existing primary acquired melanosis. The lesion has a smooth surface and can be pigmented or } \\
\text { amelanotic. }{ }^{1,18}\end{array}$ \\
\hline Pyogenic granuloma & A fleshy, red, vascular mass that occurs after surgery or trauma. Responds well to topical steroids and beta-blockers. ${ }^{12,19}$ \\
\hline Dermoid & $\begin{array}{l}\text { A congenital yellow-white mass that typically occurs at the infero temporal limbus. Often contains fine hair on slit lamp } \\
\text { examination. }{ }^{18}\end{array}$ \\
\hline Lympho-proliferative conditions & Typically presents as a painless pink mass, classically called a salmon patch. ${ }^{12}$ \\
\hline Pseudo-epitheliomatous hyperplasia & $\begin{array}{l}\text { Rapidly growing leukoplakic lesion of the conjunctiva. }{ }^{1} \text { Usually associated with a pre-existing condition such as pterygium or } \\
\text { pingueculum. }{ }^{12}\end{array}$ \\
\hline Limbal stem cell failure & $\begin{array}{l}\text { Loss of limbal stem cells, resulting in a compromised corneal epithelium and loss of the limbal barrier function with peripheral } \\
\text { corneal neovascularisation. }{ }^{17}\end{array}$ \\
\hline
\end{tabular}

OSSN, Ocular surface squamous neoplasia. 


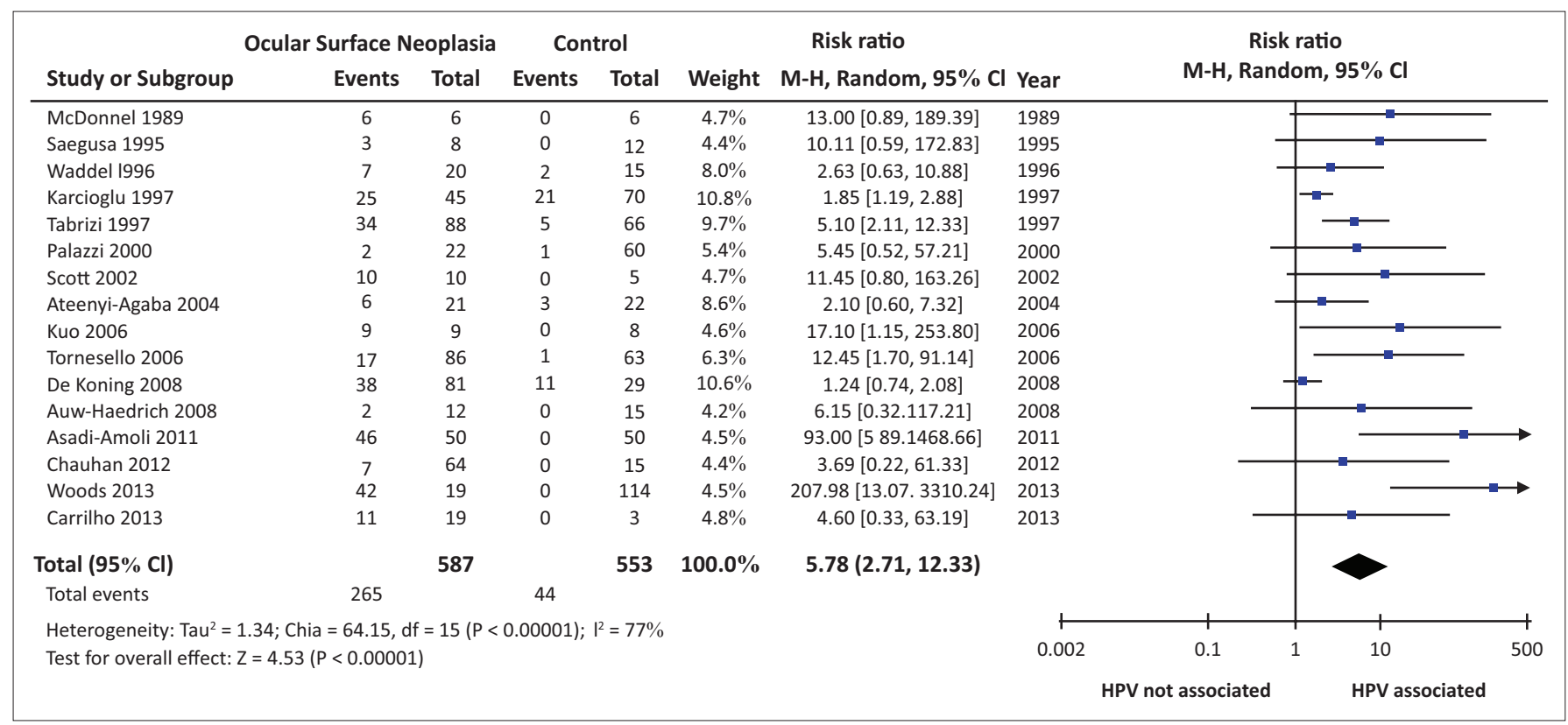

Source: Created with Review Manager (RevMan) [Computer program], version 5.3. The Nordic Cochrane Centre, Copenhagen, The Cochrane Collaboration, 2014 $\mathrm{Cl}$, confidence intervals; HPV, human papilloma virus.

FIGURE 2: Forest plot showing the risk ratio of mucosal and cutaneous human papilloma virus as an association with ocular surface squamous neoplasia. The overall risk ratio was 5.78 and $95 \%$ confidence interval: $2.71-12.33$, with high heterogeneity of studies.

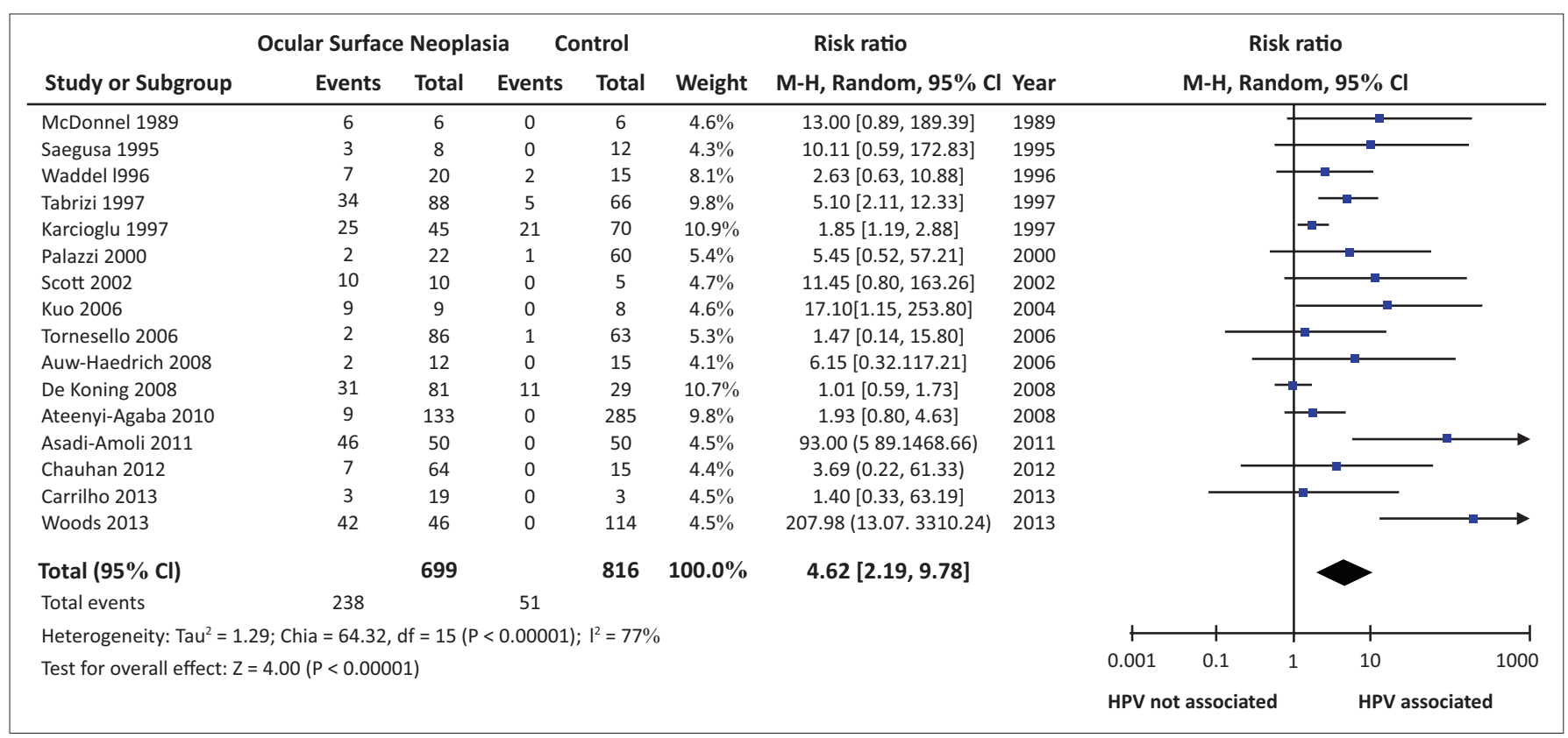

Source: Created with Review Manager (RevMan) [Computer program], version 5.3. The Nordic Cochrane Centre, Copenhagen. The Cochrane Collaboration, 2014 $\mathrm{Cl}$, confidence intervals; HPV, human papilloma virus.

FIGURE 3: Forest plot showing the risk ratio for mucosal human papilloma virus as an association with ocular surface squamous neoplasia. The overall risk ratio was 4.62 and $95 \%$ confidence interval: $2.19-9.78$, with a high heterogeneity of studies.

Agaba et al..$^{35}$ was the first to investigate and find an association between cutaneous HPV and OSSN. They used PCR to identify the presence of mucosal and cutaneous subtypes in 21 OSSN lesions and 22 controls, finding no association between mucosal HPV and OSSN (vs. 9\% of controls) but found cutaneous HPV in $86 \%$ of OSSN cases (vs. $36 \%$ of controls). This finding was repeated in subsequent studies and the subtypes 5 and 8 were found to have the highest association. ${ }^{36,37}$ Studies following this have investigated both mucosal and cutaneous HPV types but without consistent results. $27,28,29,33,35,36,37,38,39,40,41,42,43,44,45,46,47,48,49,50,51,52,53$
Figures 2-4 show an association between HPV and OSSN, with results from studies investigating mucosal HPV showing a high degree of heterogeneity, whilst the results from studies of cutaneous HPV group have low heterogeneity. This may suggest a more consistent association between cutaneous HPV and OSSN, although the study numbers are smaller. The inconsistent association may be attributed to several factors, including patient selection, HPV prevalence pattern, sample handling, testing methodology and the assays used. ${ }^{20}$ Commercial testing kits are freely available for mucosal 


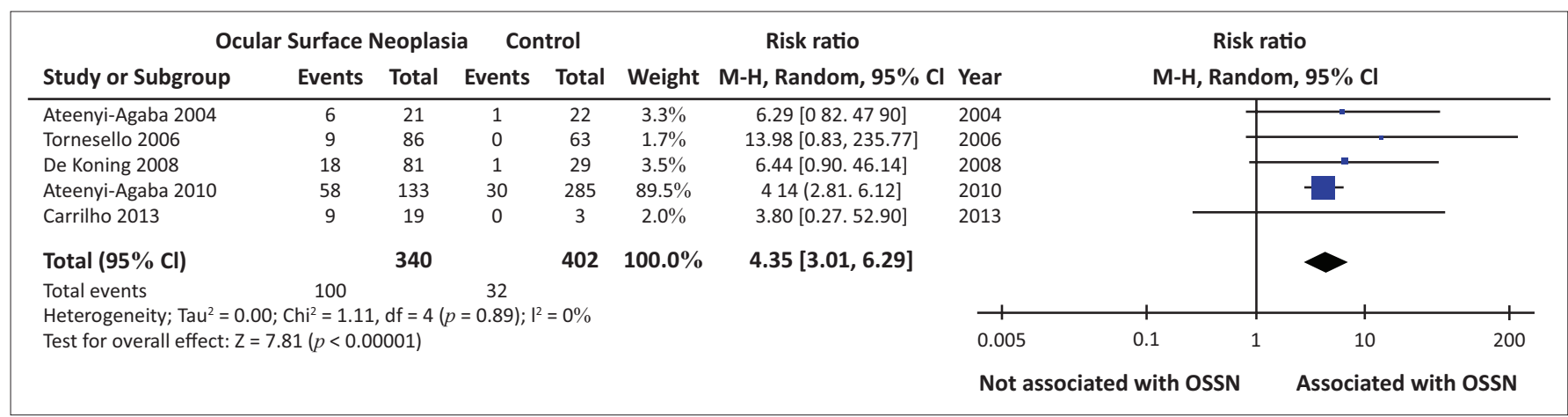

Source: Created with Review Manager (RevMan) [Computer program], version 5.3. The Nordic Cochrane Centre, Copenhagen. The Cochrane Collaboration, 2014

$\mathrm{Cl}$, confidence interval; OSSN, ocular surface squamous neoplasia.

FIGURE 4: Forest plot showing the risk ratio for cutaneous human papilloma virus as an association with ocular surface squamous neoplasia. The overall risk ratio was 4.35 and $95 \% \mathrm{Cl}$ : 3.01-6.29, with a low heterogeneity of studies.

subtypes of HPV but limited for cutaneous HPV types. Many studies therefore only tested for limited types but earlier studies favoured the mucosal types. Altogether, this has resulted in inconsistent reports and uncertainty on the role of different types of HPV in the pathogenesis of OSSN. ${ }^{3}$ The different HPV types are relevant when considering public health immunisation programmes and their impact on cancer prevention. Current HPV vaccines only cover mucosal types and would therefore not offer any protection if cutaneous HPV is the leading associated type.

\section{Human immunodeficiency virus}

Ocular surface squamous neoplasia is recognised as an acquired immune deficiency syndrome (AIDS)-related cancer with $60 \%-77 \%$ of patients with OSSN in Africa infected with HIV. In endemic countries, it has been found to be the presenting feature of HIV infection in 50\% - 86\% of patients. ${ }^{3,954,55}$ There has been a steady increase in the incidence of OSSN with the onset of the HIV pandemic. This has been reported in the United States, Tanzania, Zimbabwe and Uganda, where the incidence of OSSN increased sixfold between 1970 and $1988 .{ }^{3,56}$ Human immunodeficiency virus increases the risk of OSSN by 8-19-fold, with the highest risk in the first 2 years of AIDS., ${ }^{3,9,32}$ The association is assumed to be related to decreased immunosurveillance and increased oncogenic viral infections (HPV); however, this risk has been found to be independent of HIV category, CD4 count and duration of infection. ${ }^{3,9,49}$ A study conducted by Gichuhi et al. ${ }^{20}$ found a strong association with HIV positive patients not on highly active antiretroviral therapy (HAART) (OR: 48.42, 95\% CI: 7.73-303.31), compared to patients on HAART, who were at a lower risk (OR: 19.16, 95\% CI: 6.60-55.57). Although incidence of OSSN does not have a linear relationship with CD4 count, it was also found that a CD4 count of less than $500 / \mathrm{mm}^{3}$ was associated with an increased risk of OSSN, and a CD4 count of more than $500 / \mathrm{mm}^{3}$ inferring no additional risk. Human immunodeficiency virus is probably not an isolated risk factor, as $30 \%$ of OSSN in SSA is not associated with HIV..$^{20}$ Age of onset is incongruent between studies, with some studies showing an earlier age of onset in HIV positive individuals, whilst others show no difference. ${ }^{57}$ Human immunodeficiency virus patients are shown to have an increased severity of OSSN, greater likelihood of bilaterality, worse prognosis and a higher chance of recurrence..$^{20,54,57,58}$

\section{Other associated factors}

Vitamin A is required for the normal health of mucosal membranes, and a deficiency thereof has been associated with the development of OSSN.${ }^{10}$ Gichuhi et al..$^{20}$ found lower median retinol levels in OSSN patients when compared with controls (44.9 ug/dL vs. $51.0 \mathrm{ug} / \mathrm{dL}, p=0.03$ ). Vitamin $\mathrm{A}$ is stored in the liver and released to maintain constant serum levels. ${ }^{17}$ Although vitamin A deficiency is caused by decreased dietary intake, it has been also associated with HIV infection. ${ }^{8}$ Artificially low vitamin A levels have been found during HIV seroconversion, which do not respond to vitamin A supplementation. It is therefore useful to review C-reactive protein levels when interpreting serum vitamin A levels. ${ }^{8,59}$

Smoking is commonly cited as a risk factor for OSSN. This is based on a small case control study comprising 38 participants, which found an association between cigarette smoking and OSSN. ${ }^{21}$ Gichuhi et al. ${ }^{20}$ found no association in a case control study conducted in Kenya. Similarly, no association was found in a study conducted in India. ${ }^{57}$

Chronic ocular inflammation is a risk factor for OSSN. A strong association between allergic conjunctivitis and OSSN (OR: 30.78, 95\% CI: 4.05-234) was described in a case control study conducted in Kenya. Vernal keratoconjunctivitis (VKC) is common in Africa, with prevalence rates of up to $40 \%$ found in school-going children. Vernal keratoconjunctivitis in Africa also tends to be of limbal type. It is thought that this chronic inflammation and/or the use of topical steroids could predispose to mutations in the limbal cells and cause local immunosuppression that predisposes to OSSN. ${ }^{20}$

Exposure to petroleum products is a risk factor for developing OSSN, as described by a small case control study comprising 38 participants. The retrospective study sent out questionnaires to patients with proven OSSN, which showed a relative risk of 2.46 in participants that had exposure to oil, gasoline or grease. ${ }^{21}$ 
Immunosuppression in post-organ transplant patients has been reported to increase the risk of HPV-induced malignancies. This has been reported in a case report of OSSN in a renal transplant patient. ${ }^{60}$ Ocular surface squamous neoplasia has also been associated with leukaemia and lymphoma. ${ }^{1}$

Xeroderma pigmentosum is a condition characterised by an increased susceptibility to UV-induced DNA damage (by the formation of pyrimidine dimers) with impaired DNA repair mechanism. Patients with this condition are at an increased risk of cutaneous and conjunctival malignancies. ${ }^{1} \mathrm{~A}$ case series in India of 14 patients with xeroderma pigmentosum and OSSN was presented with a median age of 12 years. At presentation, $43 \%$ of the patients had invasive squamous cell carcinoma and the overall recurrence rate for the series was $64 \%$ with a combination of medical and surgical therapy. ${ }^{61}$

\section{Conclusion}

Ocular surface squamous neoplasia is the most common ocular tumour, with the highest incidence found in SSA. Ultraviolet-B exposure is the primary risk factor, with HPV, HIV and vitamin A deficiency playing contributory roles. The role of HPV remains poorly defined because of heterogeneity between studies. The HIV pandemic has resulted in an increased incidence as well as severity and higher risk of recurrence of this disease.

\section{Acknowledgements Competing interests}

The authors have declared that no competing interests exist.

\section{Authors' contributions}

R.H. is the primary author of this work. S.W. and P.M. contributed to the development, academic content and review of this work.

\section{Ethical considerations}

This article followed all necessary ethical standards.

\section{Funding information}

This research received no specific grant from any funding agency in the public, commercial or not-for-profit sectors.

\section{Data availability statement}

Data sharing is not applicable to this article as no new data were created or analysed in this study.

\section{Disclaimer}

The views and opinions expressed in this article are those of the authors and do not necessarily reflect the official policy or position of any affiliated agency of the authors.

\section{References}

1. Lee GA, Hirst LW. Ocular surface squamous neoplasia. Surv Ophthalmol 1995;39(6):429-450. https://doi.org/10.1016/S0039-6257(05)80054-2

2. Shields $\mathrm{CL}$, Chien IL, Surakiatchanukul T, et al. Conjunctival tumors: Review of clinical features, risks, biomarkers, and outcomes - The $2017 \mathrm{~J}$. Donald M. Gass Lecture. Asia Pac J Ophthalmol. 2017;6(2):109-120. https://doi.org/10.22608/ APO. 201710

3. Gichuhi S, Sagoo MS, Weiss HA, et al. Epidemiology of ocular surface squamous neoplasia in Africa. Trop Med Int Health. 2013;18(12):1424-1443. https://doi. org/10.1111/tmi.12203

4. Statistics South Africa. Mid-year population estimates: 2018. Pretoria: Stats SA, 2018; p. 26.

5. Gichuhi S, Ohnuma S, Sagoo MS, et al. Pathophysiology of ocular surface squamous neoplasia. Exp Eye Res. 2014;129:172-182. https://doi.org/10.1016/j.exer.2014.10.015

6. Clifford GM, Gallus $S$, Herrero R, et al. Worldwide distribution of human papillomavirus types in cytologically normal women in the International Agency for Research on Cancer HPV prevalence surveys: A pooled analysis. Lancet. 2005;366(9490):991-998.

7. Chalkia A, Bontzos G, Spandidos D, et al. Human papillomavirus infection and ocular surface disease (review). Int J Oncol. 2019;54(5):1503-1510. https://doi.org/10.3892/ ijo.2019.4755

8. Baeten JM, McClelland RS, Richardson BA, et al. Vitamin A deficiency and the acute phase response among HIV-1-infected and -uninfected women in Kenya. J Acquir Immune Defic Syndr. 2002;31:243-249. https://doi.org/10.1097/00126334 200210010-00016

9. Tananuvat N, Lertprasertsuke N. Ocular Surface Squamous Neoplasia. In: Srivastava S, editor., IntechOpen: Intraepithelial Neoplasia. 2012. https://doi.org/10.5772/ 32238

10. Basti S, Macsai MS. Ocular surface squamous neoplasia. Cornea. 2003;22(7): 687-704. https://doi.org/10.1097/00003226-200310000-00015

11. Atallah M, Joag M, Galor A, et al. Role of high resolution optical coherence tomography in diagnosing ocular surface squamous neoplasia with coexistin ocular surface diseases. Ocul Surf. 2017;15(4):688-695. https://doi.org/10.1016/j. jtos.2017.03.003

12. Honavar S, Manjandavida F. Tumors of the ocular surface: A review. Indian J Ophthalmol. 2015;63(3):187. https://doi.org/10.4103/0301-4738.156912

13. Tunc $M$, Char $\mathrm{DH}$, Crawford B, et al. Intraepithelial and invasive squamous cell carcinoma of the conjunctiva: Analysis of 60 cases. Br J Ophthalmol. 1999;83(1) 98-103. https://doi.org/10.1136/bjo.83.1.98

14. McKelvie PA. Squamous cell carcinoma of the conjunctiva: A series of 26 cases. $\mathrm{Br}$ J Ophthalmol. 2002;86(2):168-173. https://doi.org/10.1136/bjo.86.2.168

15. Amin MB, Edge SB, Greene FL, et al., editors. AJCC cancer staging manual. Cham Springer; 2017. https://doi.org/10.1007/978-3-319-40618-3

16. Margo CE, Mancera N. Determining tumor category of ocular surface squamous neoplasia: Science or art? Ann Transl Med. 2018;6(Suppl. 2):S121-S121. https:// doi.org/10.21037/atm.2018.12.15

17. Krachmer JH, Mannis MJ, Holland EJ, editors. Surgery of the cornea and conjunctiva. 3rd ed. Maryland Heights, MO: Mosby Elsevier; 2011.

18. Shields CL, Shields JA. Tumors of the conjunctiva and cornea. Surv Ophthalmol. 2004;49(1):3-24. https://doi.org/10.1016/j.survophthal.2003.10.008

19. Oke I, Alkharashi M, Petersen RA, et al. Treatment of ocular pyogenic granuloma with topical timolol. JAMA Ophthalmol. 2017;135:383. https://doi.org/10.1001/ jamaophthalmol.2017.0110

20. Gichuhi S, Macharia E, Kabiru J, et al. Risk factors for ocular surface squamous neoplasia in Kenya: A case-control study. Trop Med Int Health. 2016;21(12): 1522-1530. https://doi.org/10.1111/tmi.12792

21. Napora C, Cohen EJ, Genvert GI, et al. Factors associated with conjunctival intraepithelial neoplasia: A case control study. Ophthalmic Surg. 1990;21(1):27-30.

22. Newton R, Ferlay J, Reeves $G$, et al. Effect of ambient solar ultraviolet radiation on incidence of squamous-cell carcinoma of the eye. Lancet Lond Engl. 1996 347(9013):1450-1451. https://doi.org/10.1016/s0140-6736(96)91685-2

23. Coroneo M. Ultraviolet radiation and the anterior eye: Eye contact lens. Sci Clin Pract. 2011;37(4):214-224. https://doi.org/10.1097/ICL.0b013e318223394e

24. Emmanuel B, Ruder E, Lin S-W, et al. Incidence of squamous-cell carcinoma of the conjunctiva and other eye cancers in the NIH-AARP diet and health study. Ecancermedicalscience. 2012;6:254. https://doi.org/10.3332/ecancer.2012.254

25. Clear AS, Chirambo MC, Hutt MS. Solar keratosis, pterygium, and squamous cell carcinoma of the conjunctiva in Malawi. Br J Ophthalmol. 1979;63(2):102-109. https://doi.org/10.1136/bjo.63.2.102

26. Ateenyi-Agaba C. Conjunctival squamous-cell carcinoma associated with HIV infection in Kampala, Uganda. Lancet. 1995;345(8951):695-696. https://doi. org/10.1016/S0140-6736(95)90870-6

27. Asadi-Amoli F, Heidari AB, Jahanzad I, et al. Detection of human papillomavirus in squamous cell carcinoma of conjunctiva by nested PCR: A case control study in Iran. Acta Med Iran. 2011;49(11):707-714.

28. McDonnel JM, Mayr AJ, Martin WJ. DNA of human papillomavirus type 16 in dysplastic and malignant lesions of the conjunctiva and cornea. N Engl J Med. 1989;320:1442-1446. https://doi.org/10.1056/NEJM198906013202202

29. Lauer SA, Malter JS, Ralph Meier J. Human papillomavirus type 18 in conjunctival intraepithelial neoplasia. Am J Ophthalmol. 1990;110(1):23-27. https://doi. org/10.1016/S0002-9394(14)76932-6 
30. Tuppurainen $\mathrm{K}$, Raninen $\mathrm{A}$, Kosunen $\mathrm{O}$, et al. Squamous cell carcinoma of the conjunctiva. Acta Ophthalmol (Copenh). 1992;70(2):248-254 https://doi.org/10.1111/ j.1755-3768.1992.tb04132.x

31. Saegusa M, Takano $Y$, Hashimura $M$, et al. HPV type 16 in conjunctival and junctional papilloma, dysplasia, and squamous cell carcinoma. J Clin Pathol. 1995;48(12):1106-1110. https://doi.org/10.1136/jcp.48.12.1106

32. Waddell KM, Lewallen S, Lucas SB, et al. Carcinoma of the conjunctiva and HIV infection in Uganda and Malawi. Br J Ophthalmol. 1996;80(6):503-508. https:// doi.org/10.1136/bjo.80.6.503

33. Tabrizi SN, McCurrach FE, Drewe RH, et al. Human papillomavirus in corneal and conjunctival carcinoma. Aust NZ J Ophthalmol. 2007;25:211-215. https://doi. org/10.1111/j.1442-9071.1997.tb01394.x

34. Karcioglu ZA, Issa TM. Human papilloma virus in neoplastic and non-neoplastic conditions of the external eye. Br J Ophthalmol. 1997;81(7):595-598. https://doi. org/10.1136/bjo.81.7.595

35. Ateenyi-Agaba C, Weiderpass E, Smet A, et al. Epidermodysplasia verruciformis human papillomavirus types and carcinoma of the conjunctiva: A pilot study. Br J Cancer. 2004;90(9):1777-1779. https://doi.org/10.1038/sj.bjc.6601743

36. Ateenyi-Agaba $C$, Franceschi $S$, Wabwire-Mangen $F$, et al. Human papillomavirus infection and squamous cell carcinoma of the conjunctiva. Br J Cancer. 2010;102(2): 262-267. https://doi.org/10.1038/sj.bjc.6605466

37. De Koning MN, Waddell K, Magyezi J, et al. Genital and cutaneous human papillomavirus (HPV) types in relation to conjunctival squamous cell neoplasia: A case-control study in Uganda. Infect Agent Cancer. 2008;3:12. https://doi.org/ case-control study in Ug
$10.1186 / 1750-9378-3-12$

38. Waddell K, Magyezi J, Bousarghin L, et al. Antibodies against human papillomavirus type 16 (HPV-16) and conjunctival squamous cell neoplasia in Uganda. Br J Cancer. 2003;88(12):2002-2003. https://doi.org/10.1038/sj.bjc.6600950

39. Palazzi MA, Erwenne CM, Villa LL. Detection of human papillomavirus in epithelia lesions of the conjunctiva. Sao Paulo Med J. 2000;118(5):125-130. https://doi. org/10.1590/S1516-31802000000500003

40. Eng H-L, Lin T-M, Chen S-Y, et al. Failure to detect human papillomavirus DNA in malignant epithelial neoplasms of conjunctiva by polymerase chain reaction. Am J Clin Pathol. 2002;117(3):429-436. https://doi.org/10.1309/RVUP-QMU3-5X6W3CQ1

41. Scott IU, Karp CL, Nuovo GJ. Human papillomavirus 16 and 18 expression in conjunctival intraepithelial neoplasia. Ophthalmology. 2002;109(3):542-547. https://doi.org/10.1016/S0161-6420(01)00991-5

42. Tulvatana W. Risk factors for conjunctival squamous cell neoplasia: A matched case-control study. Br J Ophthalmol. 2003;87(4):396-398. https://doi.org/10.1136/ bjo.87.4.396

43. Moubayed $\mathrm{P}$, Mwakyoma H, Schneider DT. High frequency of human papillomavirus $6 / 11,16$, and 18 infections in precancerous lesions and squamous cell carcinoma of the conjunctiva in subtropical Tanzania. Am J Clin Pathol. 2004;122(6):938-943. https://doi.org/10.1309/T189UWWVB71M9VRC

44. Tornesello ML, Duraturo ML, Waddell KM, et al. Evaluating the role of human papillomaviruses in conjunctival neoplasia. Br J Cancer. 2006;94(3):446-449. https://doi.org/10.1038/sj.bjc.6602921

45. Ateenyiagaba C, Weiderpass E, Tommasino M, et al. Papillomavirus infection in the conjunctiva of individuals with and without AIDS: An autopsy series from Uganda. Cancer Lett. 2006;239(1):98-102. https://doi.org/10.1016/j.canlet.2005.07.024
46. Sen S, Sharma A, Panda A. Immunohistochemical localization of human papillomavirus in conjunctival neoplasias: A retrospective study. Indian J Ophthalmol. 2007;55(5):361. https://doi.org/10.4103/0301-4738.33822

47. Guthoff R, Marx A, Stroebel P. No evidence for a pathogenic role of human papillomavirus infection in ocular surface squamous neoplasia in Germany. Curr Eye Res. 2009;34(8):666-671. https://doi.org/10.1080/0271368090 3007162

48. Manderwad GP, Kannabiran C, Honavar SG, et al. Lack of association of high-risk human papillomavirus in ocular surface squamous neoplasia in India. Arch Pathol Lab Med. 2009;133(8):5.

49. Simbiri KO, Murakami M, Feldman M, et al. Multiple oncogenic viruses identified in Ocular surface squamous neoplasia in HIV-1 patients. Infect Agent Cancer. 2010;5:6. https://doi.org/10.1186/1750-9378-5-6

50. Yu JJ, Fu P, Pink JJ, et al. HPV infection and EGFR activation/alteration in HIV infected East African patients with conjunctival carcinoma. PLoS One. 2010;5(5):e10477. https://doi.org/10.1371/journal.pone.0010477

51. Woods $M$, Chow $S$, Heng $B$, et al. Detecting human papillomavirus in ocula surface diseases. Investig Opthalmol Vis Sci. 2013;54(13):8069. https://doi. org/10.1167/iovs.13-13140

52. Carrilho C, Gouveia P, Yokohama H, et al. Human papillomaviruses in intraepithelial neoplasia and squamous cell carcinoma of the conjunctiva: A study from Mozambique. Eur J Cancer Prev. 2013;22(6):566-568. https://doi.org/10.1097/ CEJ.0b013e328363005d

53. Afrogheh AH, Jakobiec FA, Hammon R, et al. Evaluation for high-risk HPV in squamous cell carcinomas and precursor lesions arising in the conjunctiva and lacrimal sac. Am J Surg Pathol. 2016;40(4):519-528. https://doi.org/10.1097/ PAS.0000000000000581

54. Cicinelli MV, Marchese A, Bandello F, et al. Clinical management of ocular surface squamous neoplasia: A review of the current evidence. Ophthalmol Ther 2018;7(2):247-262. https://doi.org/10.1007/s40123-018-0140-z

55. Spitzer MS, Batumba NH, Chirambo T, et al. Ocular surface squamous neoplasia as the first apparent manifestation of HIV infection in Malawi. Clin Exp Ophthalmol. 2008;36(5):422-425. https://doi.org/10.1111/j.1442-9071.2008.01794.x

56. Poole TRG. Conjunctival squamous cell carcinoma in Tanzania. $\mathrm{Br} \mathrm{J}$ Ophthalmol. 1999;83(2):177-179. https://doi.org/10.1136/bjo.83.2.177

57. Kamal S, Kaliki S, Mishra DK, et al. Ocular surface squamous neoplasia in 200 patients. Ophthalmology. 2015;122(8):1688-1694. https://doi.org/10.1016/j. ophtha.2015.04.027

58. Steele KT, Steenhoff AP, Bisson GP, et al. Ocular surface squamous neoplasia among HIV-infected patients in Botswana. S Afr Med J. 2015;105(5):379. https:// doi.org/10.7196/SAMJ.8254

59. Visser ME, Maartens G, Kossew G, et al. Plasma vitamin A and zinc levels in HIVinfected adults in Cape Town, South Africa. Br J Nutr. 2003;89(4):475. https://doi. org/10.1079/BJN2002806

60. Shome D, Honavar SG, Manderwad GP, et al. Ocular surface squamous neoplasia in a renal transplant recipient on immunosuppressive therapy. Eye. 2006;20(12) 1413-1414. https://doi.org/10.1038/sj.eye.6702270

61. Gupta N, Sachdev R, Tandon R. Ocular surface squamous neoplasia in xeroderma pigmentosum: Clinical spectrum and outcome. Graefes Arch Clin Exp Ophthalmol. 2011;249(8):1217-1221. https://doi.org/10.1007/s00417-011-1679-8 